\title{
An Essential Role for Macrophage Migration Inhibitory Factor (MIF) in Angiogenesis and the Growth of a Murine Lymphoma
}

\author{
Jason Chesney, ${ }^{1}$ Christine Metz, ${ }^{1}$ Michael Bacher, ${ }^{1}$ Tina Peng, ${ }^{1}$ \\ Andreas Meinhardt, ${ }^{2}$ and Richard Bucala ${ }^{1}$ \\ ${ }^{1}$ Laboratory of Medical Biochemistry, The Picower Institute for \\ Medical Research, Manhasset, New York, U.S.A. \\ ${ }^{2}$ Department of Anatomy and Cell Biology, Philipps University, \\ Marburg, Germany \\ Communicated by R. Bucala. Accepted January 15, 1999.
}

\begin{abstract}
Background: Macrophage migration inhibitory factor (MIF) has been shown to counterregulate glucocorticoid action and to play an essential role in the activation of macrophages and T cells in vivo. MIF also may function as an autocrine growth factor in certain cell systems. We have explored the role of MIF in the growth of the $38 \mathrm{C} 13 \mathrm{~B}$ cell lymphoma in $\mathrm{C} 3 \mathrm{H} / \mathrm{HeN}$ mice, a well-characterized syngeneic model for the study of solid tumor biology.

Materials and Methods: Tumor-bearing mice were treated with a neutralizing anti-MIF monoclonal antibody and the tumor response assessed grossly and histologically. Tumor capillaries were enumerated by immunohistochemistry and analyzed for MIF expression. The effect of MIF on endothelial cell proliferation was studied in vitro, utilizing both specific antibody and antisense oligonucleotide constructs. The role of MIF in
\end{abstract}

angiogenesis also was examined in a standard Matrigel model of new blood vessel formation in vivo.

Results: The administration of anti-MIF monoclonal antibodies to mice was found to reduce significantly the growth and the vascularization of the $38 \mathrm{C} 13 \mathrm{~B}$ cell lymphoma. By immunohistochemistry, MIF was expressed predominantly within the tumor-associated neovasculature. Cultured microvascular endothelial cells, but not $38 \mathrm{C} 13 \mathrm{~B}$ cells, produced MIF protein and required its activity for proliferation in vitro. Anti-MIF monoclonal antibody also was found to markedly inhibit the neovascularization response elicited by Matrigel implantation. Conclusion: These data significantly expand the role of MIF in host responses, and suggest a new target for the development of anti-neoplastic agents that inhibit tumor neovascularization.

\section{Introduction}

The pathogenesis of cancer is complex, involving cellular transformation and proliferation, stromal support responses such as angiogenesis, and evasion of host immune defenses (1-3). Inflammatory cytokines have been recognized in many

Address correspondence and reprint requests to: Dr. Richard Bucala, Laboratory of Medical Biochemistry, The Picower Institute for Medical Research, 350 Community Drive, Manhasset, NY 11030, U.S.A. Phone: 516-562-9406; Fax: 516-365-5286; E-mail: rbucala@picower.edu instances to play an important role in the development and growth of tumors (4). Interleukin-1 (IL-1), IL-2, hematopoietic colony-stimulating factors (CSFs), platelet-derived growth factor (PDGF), and transforming growth factor $\beta 1$ (TGF- $\beta 1$ ) each can act as an autocrine growth factor for tumor cells, and antibodies to these cytokines inhibit tumor cell proliferation in model systems (5). Growth factors such as TGF- $\beta 1$ and chemokines such as IL-8 also have been shown to have angiogenic activity and to promote the development of the supporting vas- 
culature which is necessary for solid tumor growth $(6-8)$.

Macrophage migration inhibitory factor (MIF) was originally described 30 years ago as a $\mathrm{T}$ cell-derived factor that inhibited the random migration of macrophages in vitro $(9,10)$. In more recent studies, MIF also has been found to play an essential regulatory role in macrophage activation and in mitogen- and antigen-driven $\mathrm{T}$ cell proliferation $(11,12)$. MIF is produced by these cells in response both to glucocorticoids and inflammatory stimuli, and acts to counterregulate the immunosuppressive effects of glucocorticoids on macrophage and $\mathrm{T}$ cell cytokine production (11-13). Circulating levels of MIF increase as a consequence of various systemic inflammatory conditions and neutralizing antiMIF antibodies suppress delayed-type hypersensitivity reactions, antigen-specific $\mathrm{T}$ cell activation, and the toxic response to septicemia (11,14-16).

In the present study, we report that the mediator MIF plays an essential role in the formation of new blood vessels. The administration of neutralizing anti-MIF antibodies to mice was found to significantly retard the growth of the $38 \mathrm{C} 13$ B cell lymphoma, and reduced tumor growth was associated with a marked reduction in tumor angiogenesis. In vivo, MIF was found to be expressed predominantly by tumor endothelium and in vitro, microvascular endothelial cells were found to secrete MIF protein and to require MIF to proliferate. Finally, MIF was observed to be necessary for the outgrowth of new vessels in an in vivo model of angiogenesis utilizing Matrigel implantation. These data assign a previously unexpected role for MIF in the angiogenic response, and in the resultant growth of certain neoplasms.

\section{Materials and Methods}

\section{$38 \mathrm{Cl} 3$ B Lymphoma Growth In Vivo}

38C13 B lymphoma cells (provided by J. D. Kemp, Department of Pathology, University of Iowa) were collected from exponential growth phase culture in RPMI 1640 medium containing glutamine $(300 \mu \mathrm{g} / \mathrm{ml})$, sodium pyruvate (110 $\mu \mathrm{g} / \mathrm{ml}), 2$-mercapto-ethanol, $\left(5 \times 10^{-5} \mathrm{M}\right)$, HEPES ( $10 \mathrm{mM}, \mathrm{pH} 7.2$ ), and $10 \%$ heat inactivated fetal calf serum (FCS), and then washed twice and resuspended in phosphate-buffered saline $(\mathrm{PBS})\left(1 \times 10^{6}\right.$ cells $\left./ \mathrm{ml}\right)$. Following the methods of Kemp et al. (17), groups of five $\mathrm{C} 3 \mathrm{H} /$ HeN female mice (20-25 g, Harlan, Indianapolis,
IN) were shaven on the upper flank and $0.05 \mathrm{ml}$ of the $38 \mathrm{C} 13$ cell suspension $\left(5 \times 10^{4}\right.$ cells) was injected i.d. with a 1 -ml syringe and 27-gauge needle. In the initial tumor outgrowth experiments, mice received an i.p. injection of $0.3 \mathrm{ml}$

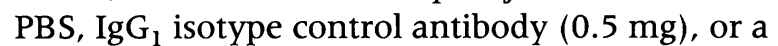
purified anti-MIF monoclonal antibody (MAb) $(0.5 \mathrm{mg})(13) 1 \mathrm{hr}$ after $38 \mathrm{Cl} 3$ cell injection and then every $24 \mathrm{hr}$ for 7 days. The anti-MIF mAb was produced as mouse ascites, precipitated with $\mathrm{NH}_{4} \mathrm{SO}_{4}$ and purified by anion exchange chromatography on FPLC (HiTrapQ, Pharmacia, Uppsala, Sweden). The lipopolysaccharide (LPS) content of anti-MIF and control antibodies was determined to be $0.05 \mathrm{fg} / \mathrm{ng}$ protein by the $\mathrm{Limu}$ lus amoebocyte lysate assay. Anti-MIF mAb was $>95 \%$ pure as determined by Coomassie blue staining/SDS-PAGE. In the established solid tumor experiments, the tumors were allowed to grow for 5 days to a mean weight of $50 \mathrm{mg}$ before treatment was begun. Mice then received an i.p. injection of $0.3 \mathrm{ml} \mathrm{PBS,} \operatorname{IgG}_{1}$ isotype control antibody $(0.5 \mathrm{mg})$, or an anti-MIF mAb $(0.5 \mathrm{mg})$ every $12 \mathrm{hr}$ for 4 days. Tumor size was determined with Vernier calipers according to the following formula: weight $(\mathrm{mg})=(\text { width }, \mathrm{mm})^{2} \times$ (length, mm)/2 (18). In addition to examining tumor weights in situ, we excised initial outgrowth tumors and directly measured their wet weights: PBS, $671.4 \pm 50.6 \mathrm{mg}$; IgGl, $693.4 \pm$ $110.9 \mathrm{mg}$; anti-MIF, $205 \pm 62.5 \mathrm{mg}(p<0.05)$. Anti-MIF monoclonal antibody was produced as mouse ascites, precipitated with ammonium sulfate, and purified by anion exchange chromatography on FPLC (HiTrapQ, Pharmacia). Statistical significance was assessed by two sample $t$-tests (assuming unequal variances) (19).

\section{Immunohistochemistry}

Tumors were excised from euthanized mice, fixed in neutral buffered $4 \%$ formalin, sectioned, and processed for immunohistochemical analyses. To assess vascularization, the deparaffinized sections were incubated with an anti-CD31 mAb (1:50 dilution) (clone MEC 13.3) (Pharmingen, San Diego, CA) or an $\operatorname{IgG}_{2 a}$ isotype control (Pharmingen). Sections then were incubated with an alkaline phosphatase-linked secondary antibody and developed with new fuchsin (Dako, Corporation, Carpinteria, CA) as substrate. To assess MIF and VWF protein expression, peroxidase-blocked $\left(3 \% \mathrm{H}_{2} \mathrm{O}_{2}\right)$ sections were incubated with an affinity-purified, monoclonal anti-MIF antibody and, following three 
washes in PBS/0.05\% Tween-20, the bound antibody was visualized using the universal LSAB-2 horseradish peroxidase kit according to the manufacturer's instructions (Dako) (15). The sections were stained with 3-amino-9-ethylcarbazole (for anti-MIF) or diaminobenzidine (for anti-vWF) as chromogenic substrate. For double-immunostaining, anti-MIF stained sections were washed and then labeled with anti-vWF $\mathrm{Ab}$, incubated with an alkaline phosphatase-linked secondary $\mathrm{Ab}$, and developed with new fuchsin (Dako) as substrate. Control sections incubated with an isotype control or without primary antibody showed no immunoreactivity.

\section{Microvascular Endothelial Cell Proliferation}

Human microvascular endothelial cells (primary, fourth passage) (Clonetics, San Diego, CA) were cultured in 96-well flat bottom plates $\left(5 \times 10^{3}\right.$ cells/well) with $100 \mu$ l Endothelial Cell Growth Medium (Clonetics) (diluted 1:5 with RPMI 1640) supplemented with $1 \%$ heat-inactivated FCS. Endothelial cell cultures were $>95 \%$ pure as demonstrated by flow cytometry for Factor VIII related antigen (clone no. F3520, Sigma Chemical Co., St. Louis, MO). Cells were incubated for $20 \mathrm{hr}$ alone as control or in the presence of $\operatorname{IgG}_{1}$ isotype control (Sigma) or neutralizing anti-MIF mAb (25-200 $\mu \mathrm{g} /$ $\mathrm{ml}$ ). In separate experiments, cells were transfected for $20 \mathrm{hr}$ by the lipofectin method (Gibco, Gaithersburg, MD) with the following phosphorothioate oligonucleotides: S-MIF:5'-GCC-ATC-ATG-CCGATG-TTC-AT-3'; AS-MIF:5'-ATG-AAC-ATCGGC-ATG-ATG-GC-3' (designed to span the MIF translation start site) $(10 \mu \mathrm{g} / \mathrm{ml})$ (Oligo's, etc., Wilsonville, OR) (20). Transfection efficiency studies were conducted with several concentrations of anti-MIF anti-sense oligonucleotides (MIF was estimated by Western blot analysis and a UMAX scanner; data not shown). The proliferative activity was measured by the incorporation of $\left[{ }^{3} \mathrm{H}\right]$ thymidine (4 $\mu \mathrm{Ci} / \mathrm{ml}$ ) (DuPont, Boston, MA) into DNA over the last $16 \mathrm{hr}$ of incubation as measured by liquid scintillation counting. Data are expressed as the mean $\pm \mathrm{SD}(n=3)$.

\section{MIF Protein Expression}

Conditioned media was obtained from microvascular dermal endothelial cells $\left(5 \times 10^{3}\right.$ cells $/ 1 \mathrm{ml}$ media) or $38 \mathrm{Cl} 3$ cells and subjected to MIF Western blot analysis. Endothelial cell conditioned media was concentrated 5-fold with Centricon concentrators, and $10 \mu \mathrm{l}$ was loaded into an $18 \%$ SDS polyacrylamide gel. Proteins were resolved by electrophoresis through $18 \%$ SDS polyacrylamide gels under reducing conditions and then transferred onto nitrocellulose membranes (Schleicher \& Schuell, Keene, NH). Membranes were incubated with polyclonal antiMIF antibody and then with donkey peroxidaseconjugated anti-rabbit IgG antibody (1:1000). MIF was visualized by development with luminol (Amersham International, Buckinghamshire, U.K.). rMIF was electrophoresed and transferred as a standard (21). Five-fold concentrated Endothelial Cell Growth Medium supplemented with $1 \%$ heat-inactivated FCS does not contain detectable MIF (Fig. 1C, lane c). Conditioned medium and lysates of $1 \times 10^{5} 38 \mathrm{C} 13$ cells were also analyzed by sandwich ELISA employing a monoclonal anti-MIF capture antibody, a polyclonal rabbit anti-MIF detector, and purified rMIF as standard $(11,13,21)$.

\section{In Vivo Angiogenesis Assay}

An in vivo angiogenesis assay using Matrigel was performed as previously described (21). Briefly, female BALB/c mice ( $\geq 6$ months old; Jackson Laboratories, Bar Harbor, ME,) were injected subcutaneously (s.c) with $0.5 \mathrm{ml}$ liquid Matrigel (Collaborative Biomedical Products, Bedford, MA) carefully mixed with aFGF (1 ng/ml; R\&D Systems, Minneapolis, MN) and heparin (64 units/ml) (and/or monoclonal antibodies, $25 \mu \mathrm{g} / \mathrm{ml}$ ) near the abdominal midline. The negative control animals (no angiogenesis) were injected with Matrigel containing heparin $(64 \mathrm{U} / \mathrm{ml})$ alone. For the antibody studies, mice were injected $30 \mathrm{~min}$ prior to Matrigel injection and every other day during the study with $500 \mu \mathrm{g}$ purified anti-MIF monoclonal antibody (or control IgG) i.p. in PBS. Mice were sacrificed 8 days after the Matrigel injection and the Matrigel plugs consisting of the animals' tissues (overlying skin and peritoneal lining) were recovered by dissection. The plugs were fixed in $10 \%$ neutral buffered formalin, cleared, paraffin embedded, and sectioned at $5 \mu \mathrm{m}$. Sections were evaluated using Masson's Trichrome stain and von Willebrand Factor staining for endothelial cells (Dako). In addition, $100 \mu \mathrm{g}$ of the Matrigel plug was used for hemoglobin analysis using the Drabkin reagent kit 525 (Sigma).

\section{Results}

Inhibition of B Cell Lymphoma Growth In Vivo

Our initial experiments were aimed at defining a potential role for MIF in tumorigenesis. The 


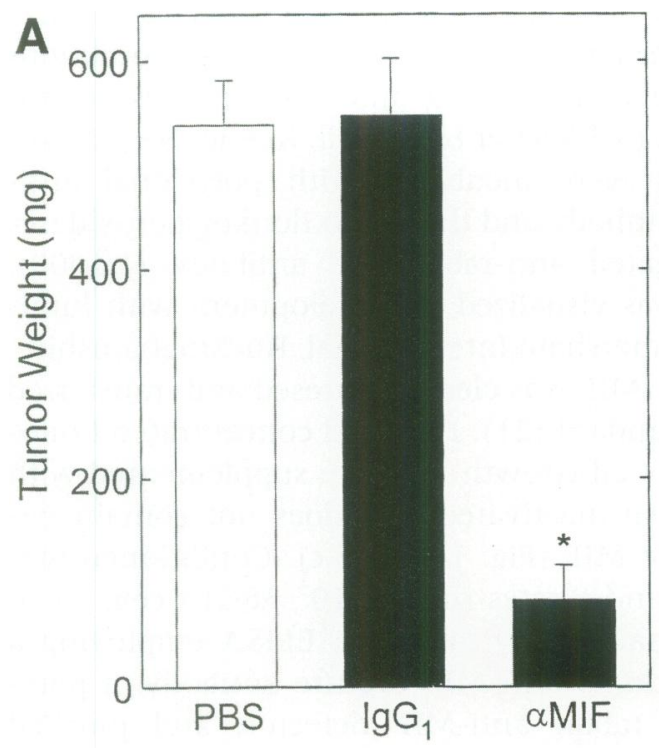

B

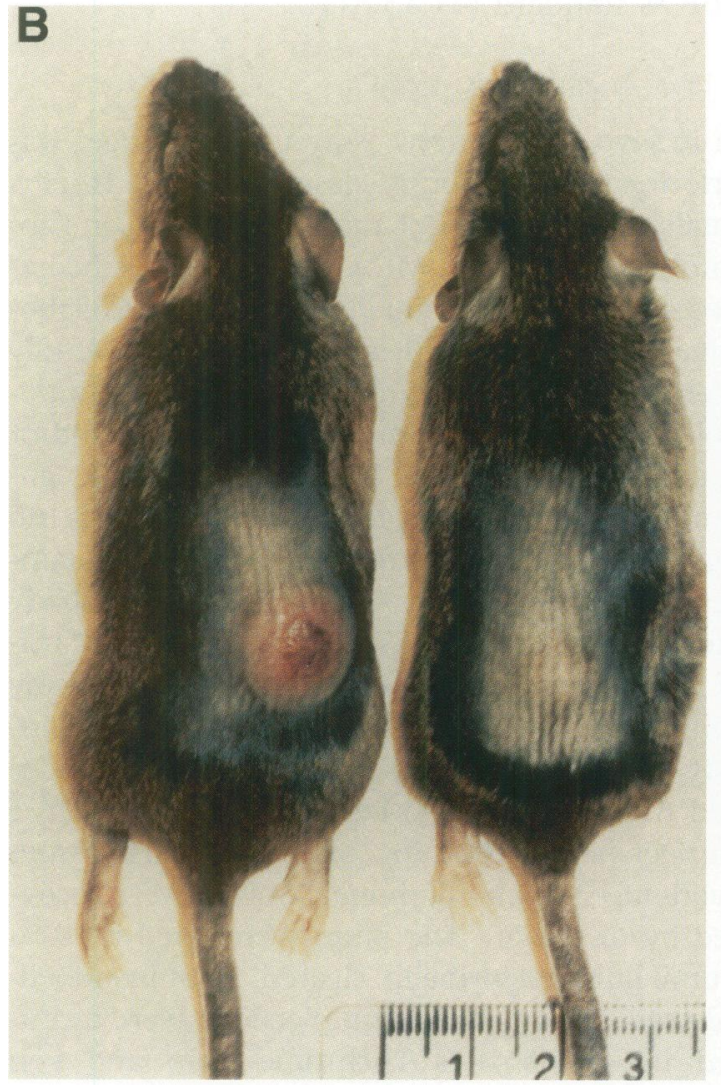

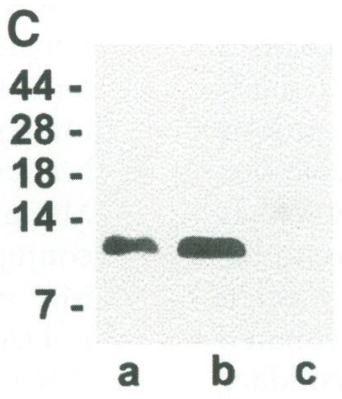

Fig. 1. Effect of anti-MIF on 38C13 B cell lymphoma initial outgrowth in vivo. (A) $\mathrm{C} 3 \mathrm{H} / \mathrm{HeN}$ mice were administered an i.d. injection of $38 \mathrm{C} 13$ tumor cells and then treated within $1 \mathrm{hr}$ and at 1 -day intervals with anti-MIF mAb, control $\mathrm{IgG}_{1} \mathrm{mAb}$, or PBS. After 7 days, the solid tumors were measured with Vernier calipers and their weights estimated. The experiments shown were performed with $0.5 \mathrm{mg}$ of pure, antiMIF mAb per injection and no effect was observed with a dose of $0.25 \mathrm{mg}$ or less per injection. Data are expressed as mean \pm SD $(n=5)$ and are representative of one experiment that was performed three times $\left({ }^{*} p<0.01\right)$. The corresponding tumor weights at 7 days were PBS: $671.4 \pm 50.6 \mathrm{mg}$; control $\mathrm{IgG}_{1}$ : $693.4 \pm 110.9 \mathrm{mg}$; and anti-MIF mAb: $205 \pm 62.5 \mathrm{mg}(p<$ 0.01 ). (B) Photomicrograph of an anti-MIF-treated (left) and an $I g G_{1}$-treated (right) tumor-bearing mouse. (C) The in vivo specificity of the anti-MIF monoclonal antibody was confirmed by Western blot analysis. Lane a, 5 ng recombinant MIF; lane b, 38C13 B cell lymphoma tissue lysate; lane c, 5-fold concentrated endothelial cell growth medium $+1 \%$ FCS, showing no detectable MIF (described further below).
$38 \mathrm{C} 13 \mathrm{~B}$ cell lymphoma of $\mathrm{C} 3 \mathrm{H} / \mathrm{HeN}$ mice is a well-characterized syngeneic model for the study of solid tumor biology $(16,22-24)$. C3H/HeN mice were administered an i.d. injection of $50,00038 \mathrm{C} 13$ tumor cells and then treated at 1-day intervals with a neutralizing anti-MIF $\mathrm{mAb}$, control $\mathrm{IgG}_{1}$, or PBS (13). After 7 days, the tumors were measured with Vernier calipers and their weights calculated. As shown in Figure 1, anti-MIF antibodies significantly reduced the initial outgrowth of the $38 \mathrm{C} 13 \mathrm{~B}$ cell lymphoma in mice compared to controls. The specificity of the anti-MIF mAb was confirmed by Western blot analysis of $38 \mathrm{C} 13$ B cell lymphoma tissue (Fig. 1C, Lane b).

The proliferation of cultured 38C13 B cell lym- 


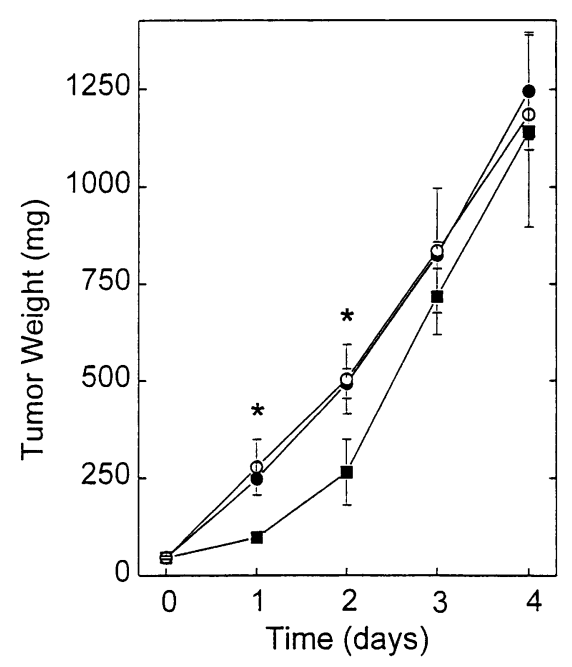

Fig. 2. Effect of anti-MIF on established 38C13 B cell lymphoma growth in vivo. $\mathrm{C} 3 \mathrm{H} / \mathrm{HeN}$ mice were administered an i.d. injection of $38 \mathrm{C} 13$ tumor cells and the tumor was allowed to grow to a mean weight of $50 \mathrm{mg}$ before any treatment was initiated (Day 0). C3H/HeN mice were then treated with anti-

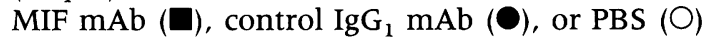
every $12 \mathrm{hr}$ for 4 days. Tumors were measured with Vernier calipers and their weights were estimated. Data are expressed as mean \pm SD $(n=5)$ and are representative of one experiment that was performed three times $\left({ }^{*} p<0.05\right)$.

phoma cells was unaffected by either anti-MIF $\mathrm{mAb}$ (at an established neutralizing concentration of $100 \mu \mathrm{g} / \mathrm{ml}$ ) (11) or MIF-specific anti-sense phosphorothioate oligonucleotides: (control IgG $\mathrm{mAb}_{1}$ $44324 \pm 6775$ cpm; anti-MIF mAb: $46674 \pm 4371$ cpm, $n=4, p>0.5$; MIF-specific sense oligo: $62399 \pm 3548 \mathrm{cpm}$; MIF-specific anti-sense oligo: $61884 \pm 7377 \mathrm{cp}, n=4, p>0.5$.) Additionally, murine rMIF at concentrations shown previously to be maximally bioactive (13) had no effect on $38 \mathrm{C} 13$ cell proliferation in vitro [PBS control $57433 \pm 2219 \mathrm{cpm} ; \mathrm{rMIF}(10 \mathrm{ng} / \mathrm{ml}): 60190 \pm$ $7377 \mathrm{cpm}, n=4, p>0.5]$. Taken together, these observations suggest that MIF plays a role in tumor outgrowth in vivo.

We next examined the ability of anti-MIF antibody to affect the growth of an established tumor. The $38 \mathrm{C} 13$ tumors thus were allowed to grow in mice for 5 days before any treatment was begun. Tumor weight was estimated and the mice then were administered anti-MIF mAb, control IgG $\mathrm{Ig}_{1}$, or PBS for 4 days. Anti-MIF mAb significantly inhibited the growth of the tumor for up to 2 days after treatment was begun (Fig. 2). The inhibitory effect of anti-MIF on tumor growth decreased over time, however, and no significant difference in tumor growth was observed after 3 and 4 days of treatment. These data contrast with the dramatic inhibition of anti-MIF that was observed during tumor outgrowth and suggest that the primary effect of MIF is relatively early during the establishment of the tumor.

\section{Reduction of Tumor Vascularization}

Neovascularization has been identified to be a critical process for the growth and metastasis of solid tumors $(26-28)$. To assess the potential role of MIF in the tumor neovascularization response, we first examined the relative vascularization of initial outgrowth tumors from mice treated with anti-MIF mAb versus those treated with control $\operatorname{IgG}_{1}$. Tumors were excised after 7 days of treatment and analyzed for the presence of capillaries by immunohistochemistry using an anti-CD31 antibody (29-32). Tumors from the anti-MIF-treated mice had significantly fewer capillaries than tumors from the $\operatorname{IgG}_{1}$-treated mice (compare Fig. 3E, F, Fig. 4). At 4 days for instance, the resultant tumors in untreated mice were found to weigh $72 \pm 24 \mathrm{mg}(n=3)$ and to contain $17.6 \pm 5.8$ capillaries $/ 200 \times$ field. In contrast, tumors permitted to grow for 7 days in anti-MIF-treated mice [and which were approximately the same size $(83 \pm 33 \mathrm{mg})]$ were found to contain only $5.0 \pm 2.5$ capillaries/hpf $(n=5$, $p<0.05$ ). That is, $38 \mathrm{C} 13 \mathrm{~B}$ cell lymphomas from anti-MIF-treated mice 7 days from initial outgrowth had fewer capillaries than similarly sized tumors from $\mathrm{IgG}_{1}$-treated mice 5 days from initial outgrowth. These data demonstrate that vessel density in tumors from anti-MIF treated mice is disproportionately reduced relative to the smaller tumor mass in this treatment group.

We next examined MIF protein expression by immunohistochemistry in sections obtained from the initial outgrowth tumors. As shown in Figure 5, capillary endothelial cells were identified to be the predominant source of MIF within the tumor, and it is important to note that no MIF was detected within the $38 \mathrm{C} 13$ tumor cells. This was further verified by the observation that neither $38 \mathrm{C} 13$ conditioned media nor cell lysates were found to contain appreciable amounts of immunoreactive MIF when analyzed by ELISA (detection limit $\approx 400 \mathrm{pg} / \mathrm{ml}$; data not shown). 


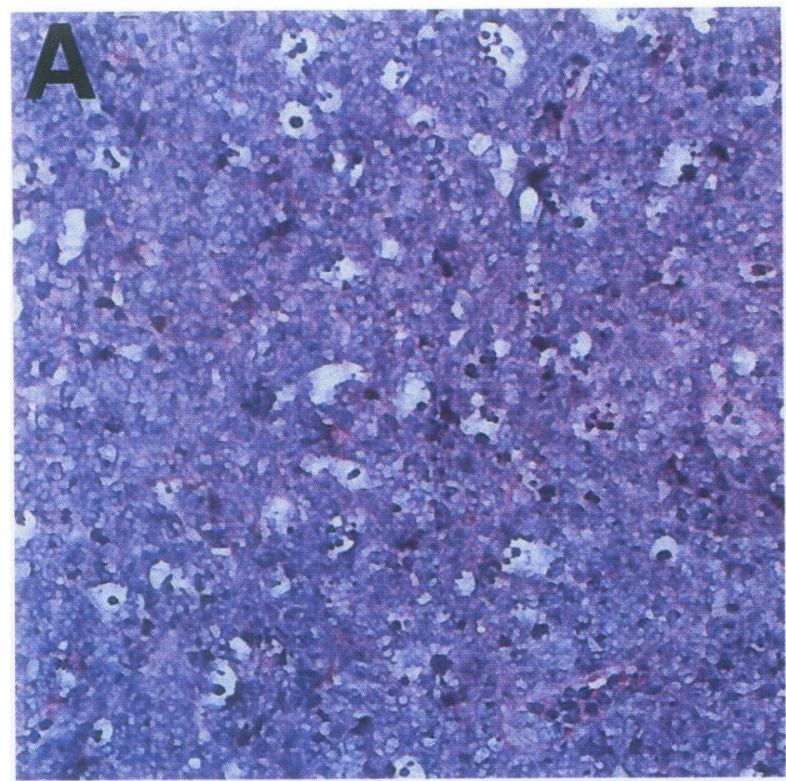

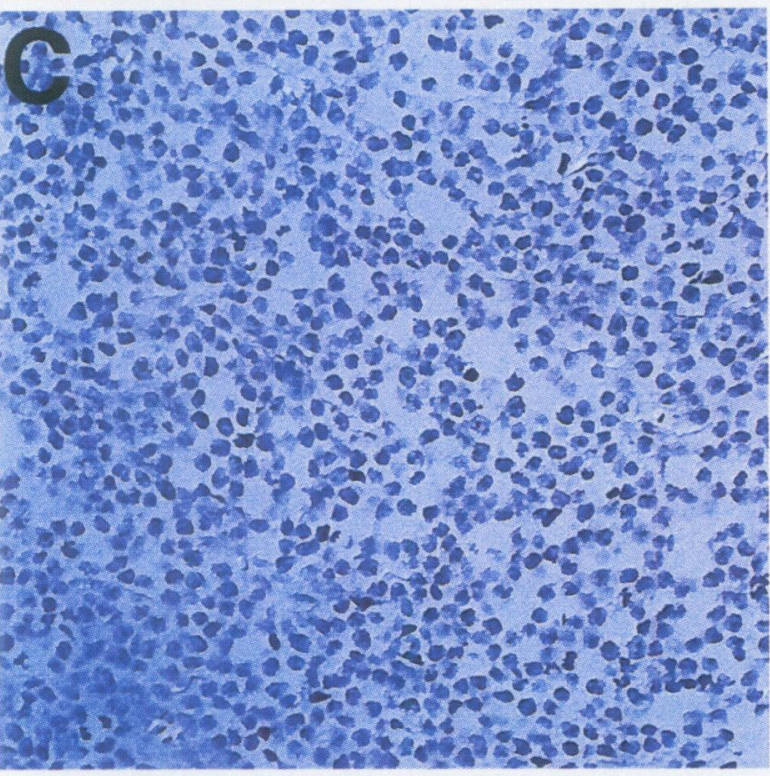

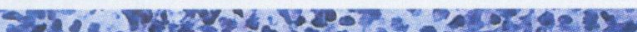

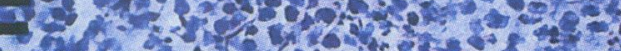

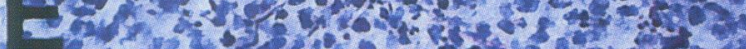

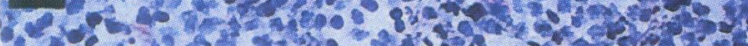

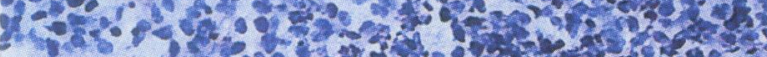

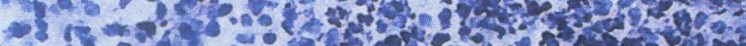

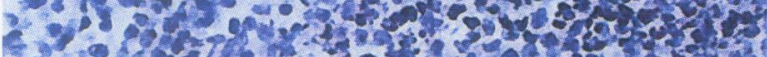

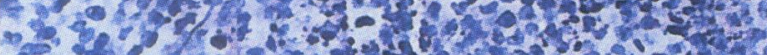

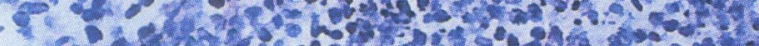

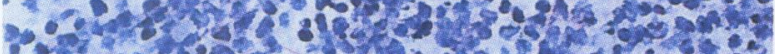

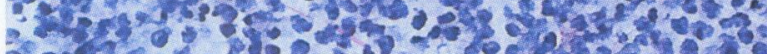

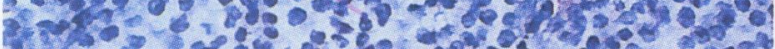

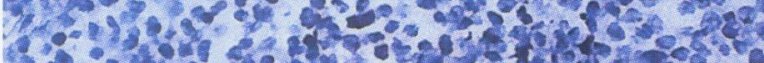

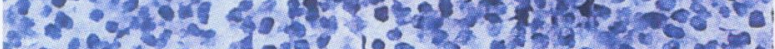

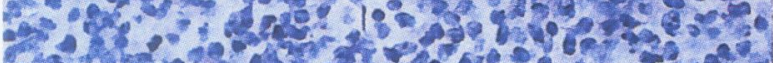

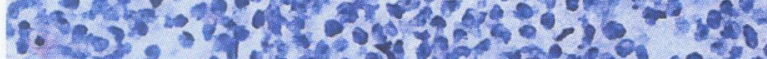

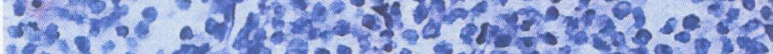

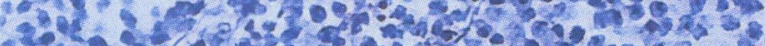

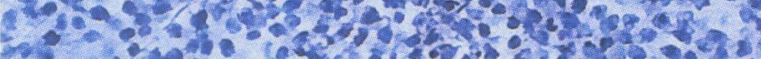

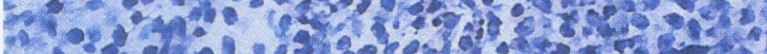

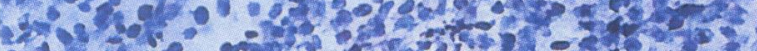

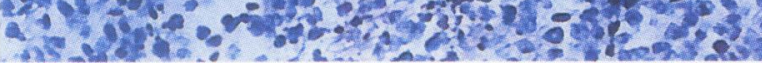

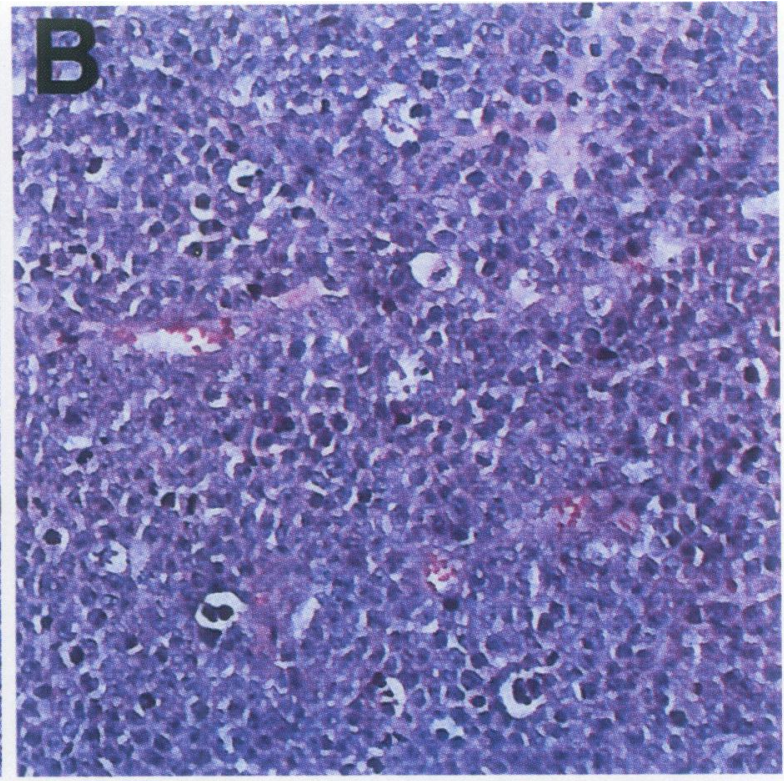

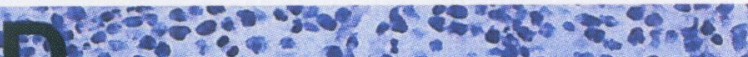

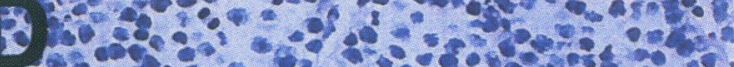

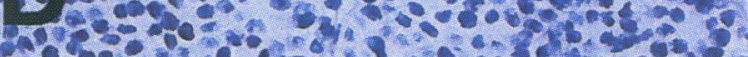

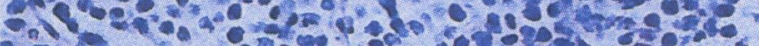

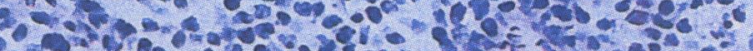

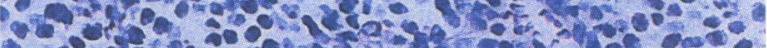
- F.- a

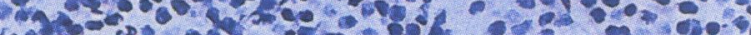

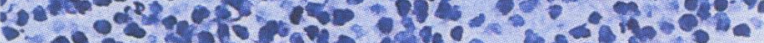

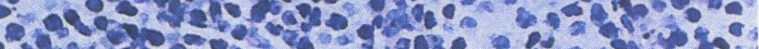

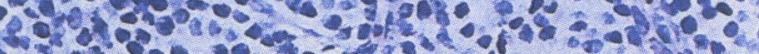

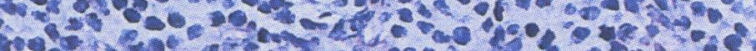

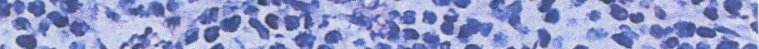

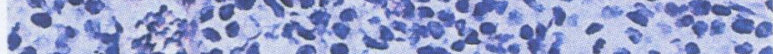

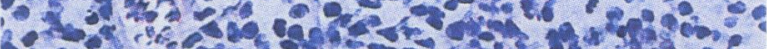

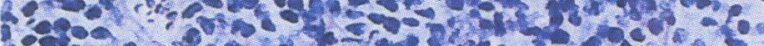

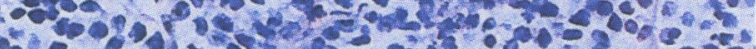

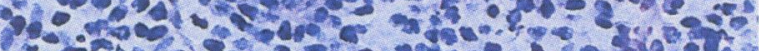

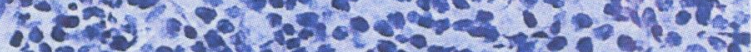

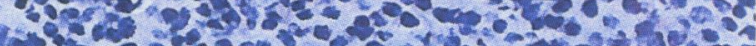

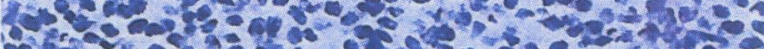

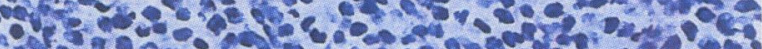

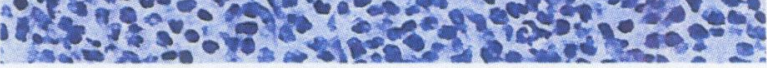

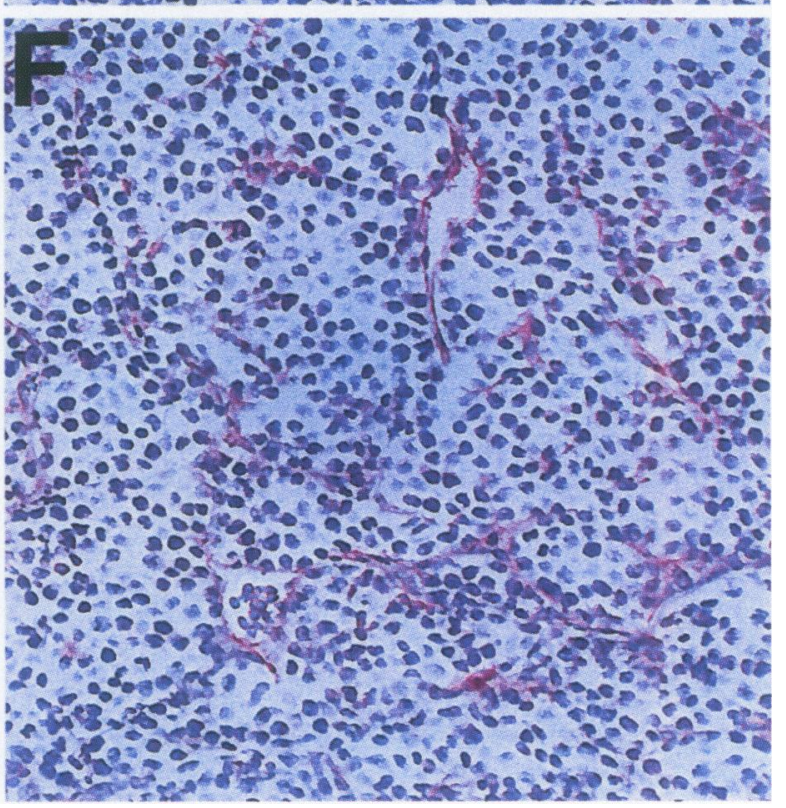




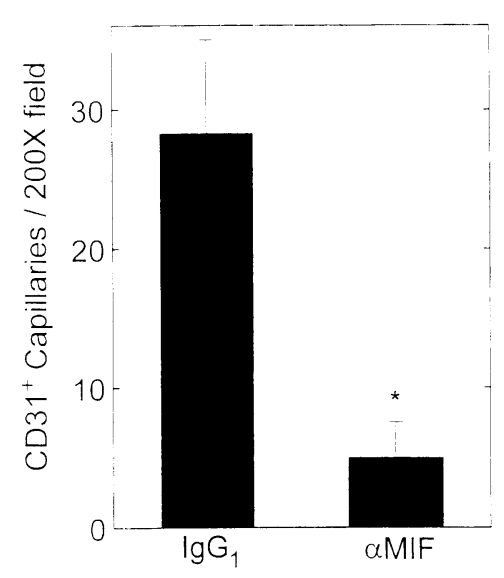

Fig. 4. Enumeration of tumor capillaries from anti-MIF- or IgG $_{1}$-treated mice. CD 31 -stained initial outgrowth tumors from $\operatorname{IgG}_{1}$ - or anti-MIFtreated mice were examined at $200 \times$ by light microscopy and the CD31-positive capillaries enumerated ( 5 fields). Data are expressed as mean \pm SD $\left(n=3 ;{ }^{*} p<0.05\right)$.

\section{Inhibition of Microvascular Endothelial Cell Proliferation In Vitro}

MIF has been shown to play an essential role in the proliferation of activated, primary $\mathrm{T}$ cells (11). We considered that MIF also may be required for the proliferation of $38 \mathrm{C} 13 \mathrm{~B}$ cell lymphoma cells or endothelial cells. 38C13 cells or primary human microvascular endothelial cells were incubated with anti-MIF or control $\operatorname{IgG}_{1}$ $\mathrm{mAb}$ and their proliferative response measured by the incorporation of $\left[{ }^{3} \mathrm{H}\right]$ thymidine into DNA. As shown in Figure 6, the addition of anti-MIF $\mathrm{mAb}$ to cultures significantly inhibited endothelial cell proliferation. As control, the addition of human rMIF to endothelial cell cultures partially reversed the ability of anti-MIF to inhibit endothelial cell proliferation $\left[\operatorname{IgG}_{1}\right.$ control $(100 \mu \mathrm{g} /$ $\mathrm{ml}), 3418 \pm 262 \mathrm{cpm}$; anti-MIF $(100 \mu \mathrm{g} / \mathrm{ml})$, $1642 \pm 375 \mathrm{cpm}$; anti-MIF $(100 \mu \mathrm{g} / \mathrm{ml})+\mathrm{rMIF}$ $(10 \mathrm{ng} / \mathrm{ml}), 2853 \pm 872,(p<0.002)]$. As in the T cell response to MIF (11), the addition of bioactive $\operatorname{rMIF}(1-100 \mathrm{ng} / \mathrm{ml})$ to endothelial cells
A

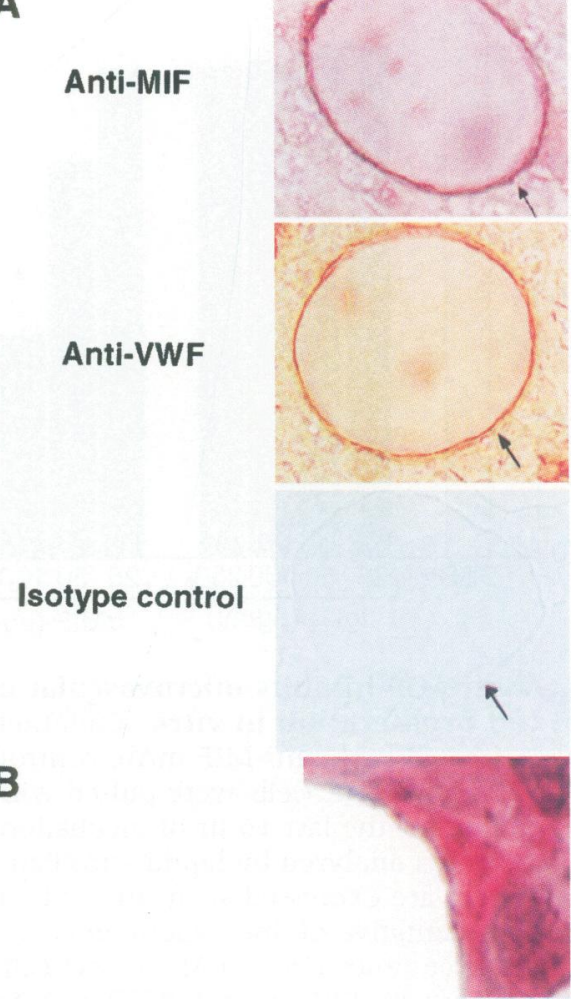

Fig. 5. MIF expression in the $38 \mathrm{C} 13 \mathrm{~B}$ cell lymphoma. $\mathrm{C} 3 \mathrm{H} / \mathrm{HeN}$ mice were administered an i.d. injection of 38C13 tumor cells. After 7 days the tumors were excised and then fixed, and adjacent sections were stained with anti-MIF mAb, anti-vWF $\mathrm{mAb}$, or an isotype control (A). The primary antibody binding was detected with a peroxidase-linked secondary antibody and 3-amino-9-ethylcarbazole (for anti-MIF) or diaminobenzidine (for anti-vWF) as chromogenic substrate. Double immunostaining with anti-MIF mAb (brown, diaminobenzidine) and anti-vWF mAb (pink, new fuchsin) shows a colocalization of MIF and $v W F$ in endothelium (B).

was not by itself mitogenic, suggesting that the endogenous level of MIF expression by cultured endothelial cells is sufficient to fully activate MIF-dependent proliferation (data not shown). By contrast, 38C13 tumor cell proliferation in vitro was unaffected by the addition of anti-MIF
Fig. 3. Effect of anti-MIF on vascularization during initial outgrowth of 38C13 B cell lymphoma. $\mathrm{C} 3 \mathrm{H} / \mathrm{HeN}$ mice were administered an i.d. injection of $38 \mathrm{C} 13$ tumor cells and then treated within $\mathrm{l} \mathrm{hr}$ and at $\mathrm{l}$-day intervals with anti-MIF $\mathrm{mAb}(\mathrm{A}, \mathrm{C}, \mathrm{E})$ or control $\mathrm{IgG}_{1} \mathrm{mAb}(\mathrm{B}, \mathrm{D}, \mathrm{F})$. The data shown were obtained with $0.5 \mathrm{mg}$ of anti-MIF $\mathrm{Ab}$ per injection, and no significant diminution in capillary density was noted with $\leq 0.25 \mathrm{mg}$ per injection. After 7 days, the tumor specimens were fixed, sectioned, and stained with hematoxylin and eosin (A, B), $\operatorname{IgG}_{2 a}$ isotype control (C, D), or antimurine $\mathrm{CD} 31 \mathrm{mAb}(\mathrm{E}, \mathrm{F})$. Binding was detected with an alkaline phosphatase-linked secondary antibody. 


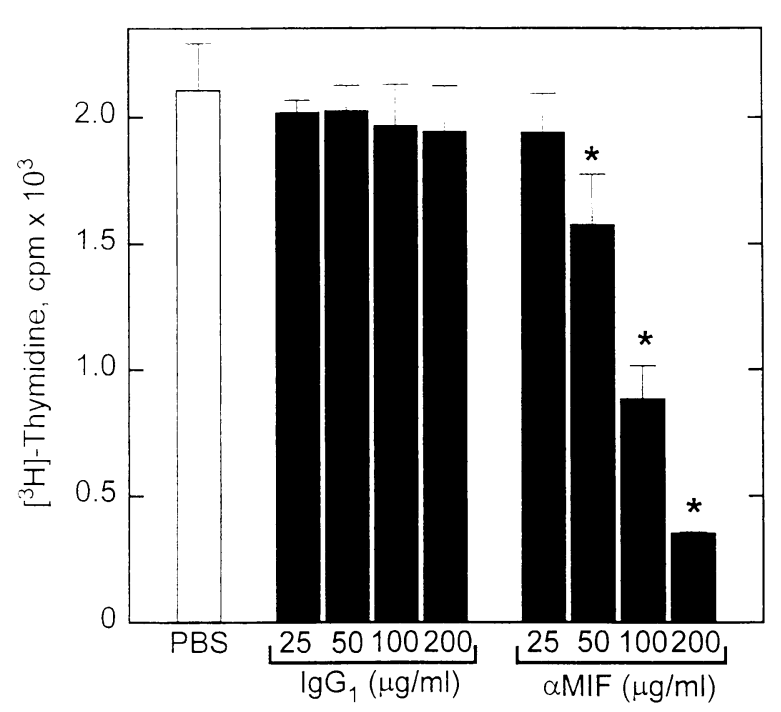

Fig. 6. Anti-MIF inhibits microvascular endothelial cell proliferation in vitro. Endothelial cells were treated with anti-MIF mAb, control IgG $\mathrm{mAb}$, or PBS for $20 \mathrm{hr}$. Cells were pulsed with $\left[{ }^{3} \mathrm{H}\right]$ thymidine for the last $16 \mathrm{hr}$ of incubation and proliferation was analyzed by liquid scintillation counting. Data are expressed as mean $\pm \operatorname{SD}(n=4)$ and are representative of one experiment that was performed three times $\left({ }^{*} p<0.01\right)$. Direct cell counts showed (cells/well): PBS control: $8512 \pm 775 ; \mathrm{IgG}_{1}$ $(25 \mu \mathrm{g} / \mathrm{ml}): 9186 \pm 1334,(50 \mu \mathrm{g} / \mathrm{ml}): 8965 \pm 980$, $(100 \mu \mathrm{g} / \mathrm{ml}): 9319 \pm 1457,(200 \mu \mathrm{g} / \mathrm{ml}): 8830 \pm$ 1876; anti-MIF mAb $(25 \mu \mathrm{g} / \mathrm{ml}): 8068 \pm 773,(50$ $\mu \mathrm{g} / \mathrm{ml}): 7718 \pm 1194,(100 \mu \mathrm{g} / \mathrm{ml}): 5513 \pm 637^{*}$, $(200 \mu \mathrm{g} / \mathrm{ml}): 4107 \pm 1173^{*}\left({ }^{*} p<0.02\right)$.

mAb $(1-200 \mu \mathrm{g} / \mathrm{ml})$ or $\mathrm{rMIF}(\mathrm{l}-100 \mathrm{ng} / \mathrm{ml}$; data not shown).

To confirm the role of MIF in endothelial cell proliferation, we next examined the response of endothelial cells to incubation with MIF-specific anti-sense (AS-MIF) or sense (S-MIF) phosphorothioate oligonucleotides. As shown in Figure 7, AS-MIF but not S-MIF inhibited both MIF protein expression and endothelial cell proliferation. These results were verified with unconcentrated supernatants using an ELISA for MIF: control, $154.2 \pm 8.9 \mathrm{ng} / \mathrm{ml}$; + MIF sense oligo, $167.7 \pm$ $17.3 \mathrm{ng} / \mathrm{ml} ;+$ MIF anti-sense oligo, $54.9 \pm 5.8$ $\mathrm{ng} / \mathrm{ml}(n=4, p<0.01)$. These data further support the notion that MIF expression by endothelial cells is necessary for their proliferation.

\section{Inhibition of Angiogenesis In Vivo}

Finally, we examined the role of MIF in an established, in vivo model of angiogenesis. The subcutaneous implantation of Matrigel, a mixture of connective tissue matrix proteins with

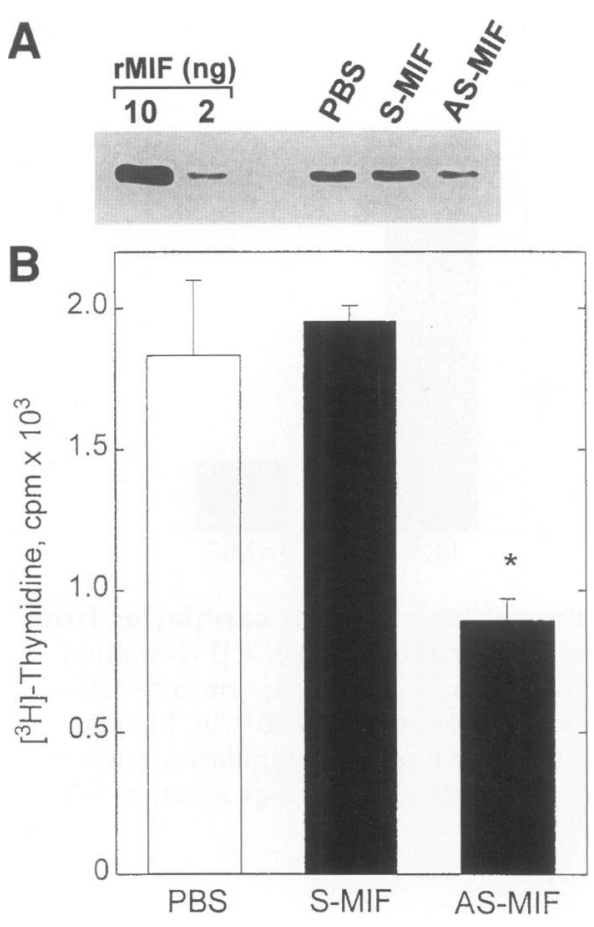

Fig. 7. MIF antisense oligonucleotides inhibit MIF expression and endothelial cell proliferation in vitro. (A). Endothelial cells were transfected with antisense human MIF (AS-MIF) or sense human MIF (S-MIF) oligonucleotides for $20 \mathrm{hr}$ and examined for MIF protein expression by Western blot analysis. RT-PCR for MIF also showed a decrease in MIF mRNA expression by AS-MIF (data not shown). (B). Transfected endothelial cells were pulsed with $\left[{ }^{3} \mathrm{H}\right]$ thymidine for the last $16 \mathrm{hr}$ of transfection and proliferation was analyzed by liquid scintillation counting. Data are expressed as mean \pm $\mathrm{SD}(n=4)$ and are representative of one experiment that was performed three times $\left({ }^{*} p<0.05\right)$.

heparin, and acidic fibroblast growth factor (aFGF), promotes a brisk neovacularization response that can be studied by histological analysis and quantified by measurement of intravascular hemoglobin (33). Mice were injected with $0.5 \mathrm{ml}$ of Matrigel near the abdominal midline and treated every other day with $0.5 \mathrm{mg}$ of an anti-MIF mAb or a control IgGl. At the end of 8 days, the implants were recovered, fixed, sectioned, and stained either with Masson's Trichrome or a specific antibody to von Willebrand Factor. As shown in Figure 8, treatment with anti-MIF antibody was associated with a dramatic reduction both in the number and the diameter of new blood vessels formed. In contrast, mouse recombinant $\operatorname{MIF}(1-100 \mathrm{ng} / \mathrm{ml})$ had no effect on in vivo angiogenesis (data not shown). Vessel formation also was quantified in 


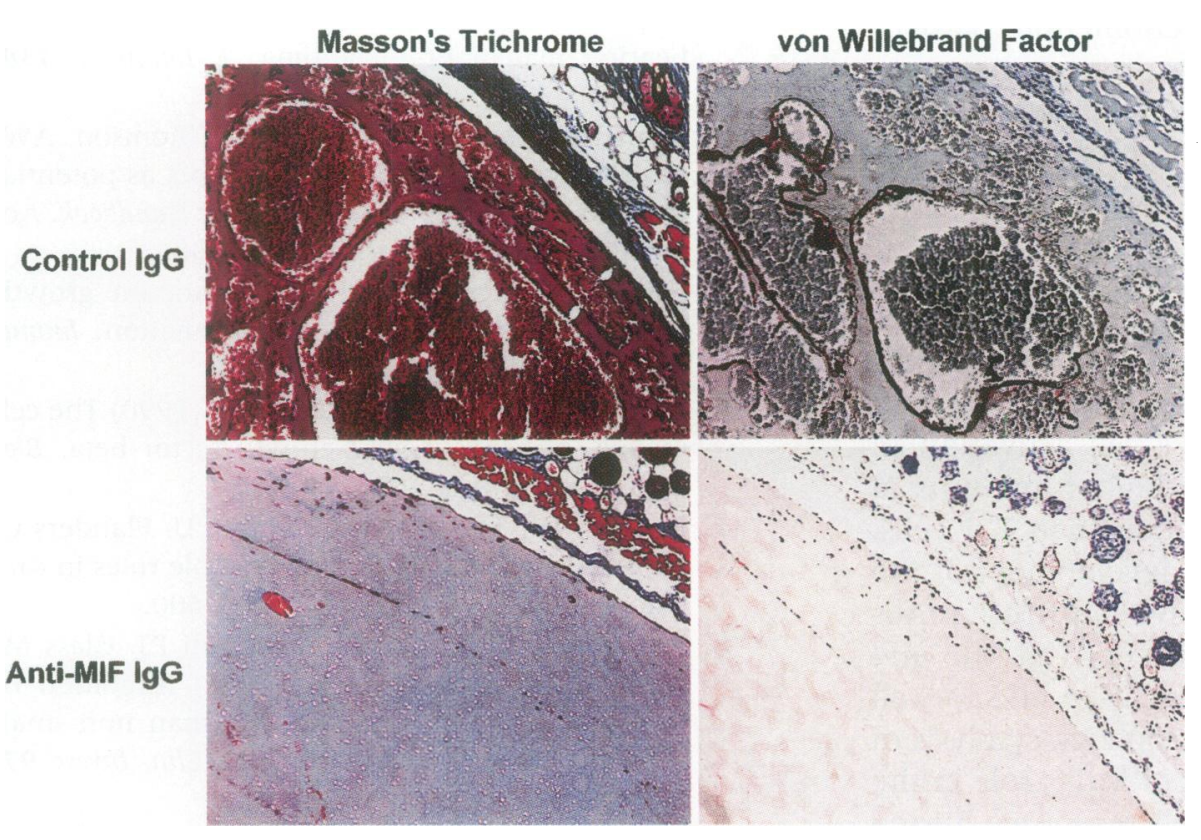

Fig. 8. Anti-MIF inhibits angiogenesis in vivo. $\mathrm{BALB} / \mathrm{c}$ mice $(n=8$ per group) were injected subcutaneously with $0.5 \mathrm{ml}$ of $\mathrm{Ma}$ trigel and treated with either anti-MIF or a control $\operatorname{IgG}_{1}$ as described in Materials and Methods. Structures stained by Masson's Trichrome include the collagenous basement membrane (blue), muscle fibers (red), Matrigel (blue/red), and red blood cells within the neovasculature (red). Representative sections are shown from one animal each $(100 \times)$. A negative control for angiogenesis was also performed, and consisted of mice implanted with Matrigel in which the aFGF had been omitted. No new blood vessels were evident in these specimens (data not shown). $100-\mu \mathrm{g}$ portions of the Matrigel plugs by assaying the content of intravascular hemoglobin. Eight days after implantation, the quantity of measured hemoglobin was $7.5 \pm 10.8 \mathrm{~g} / \mathrm{dl}$ in the anti-MIF-treated group versus $35.3 \pm 24.1 \mathrm{~g} / \mathrm{dl}$ in the control, IgGl-treated group $(n=8$ per group, $p<0.01$, Student's $t$-test statistic, twotailed). The negative angiogenesis control (no aFGF added) showed only $4.2 \pm 1.3 \mathrm{~g} / \mathrm{dl}$ of hemoglobin $(n=8, p<0.01$ versus control IgGl).

\section{Discussion}

The present study further expands the emerging role of MIF in biological responses by showing that this mediator plays a critical role in the initial outgrowth and vascularization of a mouse $B$ cell lymphoma. That MIF is required for the vascularization process complements recent observations showing that MIF mRNA and protein are expressed in dermal capillaries and inflammatory lesions in vivo (33). A strict dependence of solid tumor growth on neo-vascularization has been established by a number of model studies in vivo (26-28). This process involves several sequential steps, including (1) degradation of capillary basement membrane, (2) endothelial cell migration and proliferation, and (3) formation of a new lumen (34). In the present study, MIF was found to be expressed in tumor-associated endo- thelium and to be necessary for microvascular endothelial cell proliferation in vitro and for neovascularization in a Matrigel model in vivo. MIF thus shares certain of the proangiogenic properties of vascular endothelial cell growth factor (VEGF), transforming growth factors (TGFs), acidic (aFGF) and basic fibroblast growth factors (bFGF), and other mediators that have been investigated in recent years (35). Interestingly, acidic FGF has been found in preliminary studies to induce MIF protein expression by endothelial cells in vitro (C. Metz, personal communication). Taken together with the observation that antiMIF neutralizes acidic FGF-mediated effects in vivo, these observations suggest that MIF functions as a "downstream" mediator of acidic FGF.

Certain of the known biological properties of MIF suggest that its role in the tumor angiogenic response may be unique. MIF circulates constitutively in plasma, and has been shown to be released from immune cells by both proinflammatory stimuli and by glucocorticoids (12-14). Once released in an inflammatory setting, MIF has the capacity to override certain of the antiinflammatory and immunosuppressive effects of glucocorticoids (13). Tumors such as lymphomas are frequently sensitive to the cytolytic effects of steroids, and an additional mechanism of action of MIF may be to override these effects and promote tumor growth (36-38). Accordingly, antiMIF may serve to neutralize the MIF expressed 
within tumor sites and augment the anti-tumor effect of endogenous glucocorticoids. Further studies of this regulatory phenomenon, particularly as it may pertain to glucocorticoid-responsive, human lymphomas, will be necessary to evaluate the potential anti-tumor role of this mechanism versus the strict effects of anti-MIF on tumor angiogenesis.

An additional feature of MIF action in tumor growth that is still to be explored may be in the generation of tumor-specific helper or cytotoxic $\mathrm{T}$ cell responses. MIF has been shown to be required for antigen-specific, $T$ cell activation in vivo (11). $\mathrm{T}_{\mathrm{H}} 2$ cells produce higher amounts of MIF upon mitogenic stimulation than $\mathrm{T}_{\mathrm{H}} 1$ cells, and MIF is essential for the development of the humoral response (11). In vivo, anti-MIF mAbs may act to neutralize $\mathrm{T}_{\mathrm{H}} 2$ cell-derived MIF and promote a shift toward increased $\mathrm{T}_{\mathrm{H}} \mathrm{l}$ effector cell activity and consequent macrophage cytolysis of tumor cells. Further analysis of MIF's role in the establishment of $\mathrm{T}_{\mathrm{H}} 1 / \mathrm{T}_{\mathrm{H}} 2$ cell responses during tumorigenesis may provide important insight into the mechanisms underlying host immunity against tumors.

In conclusion, these findings support the concept that MIF plays a critical role in angiogenesis and in the establishment of certain solid tumors. Elucidation of the precise mechanism of action of MIF during the host angiogenic and immune response to tumors may contribute new information on the complex, regulatory pathways that govern neoplastic growth. The recent determination of the crystal structure of MIF, which shows a unique trimeric $\alpha / \beta$ structure, together with the discovery of an enzymatic activity for MIF should assist in the development of potential inhibitors of MIF that may find clinical utility as anti-neoplastic agents $(39,40)$.

\section{Acknowledgments}

This work was supported by grants from the NIH (AI42310-01Al) and the Arthritis Foundation.

\section{References}

1. Nicholson GL. (1987) Tumor cell instability, diversification, and progression to the metastatic phenotype: from oncogene to oncofetal expression. Cancer Res. 47: 1473-1487.

2. Folkman J. (1986) How is blood vessel growth regulated in normal and neoplastic tissue? Cancer Res. 46: 467-473.
3. Muul LM, Spiess PJ, EP Director, Rosenberg SA. (1987) Identification of specific cytolytic immune responses against autologous tumor in humans bearing malignant melanoma. J. Immunol. 138: 989-995.

4. Pugh-Humphreys RGP, Woo J, Thomson AW. (1991) Cytokines and their receptors as potential therapeutic targets. In: The Cytokine Handbook. Academic Press, New York, pp. 357-386.

5. Lang RA, Burgess AW. (1990) Autocrine growth factors and tumourigenic transformation. Immunol. Today 11: 244-249.

6. Barnard JA, Lyons RM, Moses HL. (1990) The cell biology of transforming growth factor beta. Biochim. Biophys. Acta 1032: 79-87.

7. Roberts $A B$, Thompson NL, Heine U, Flanders C, Sporn MB. (1988) TGF-beta: possible roles in carcinogenesis. Br. J. Cancer 57: 594-600.

8. Arenberg DA, Kunkel SL, Polverini PJ, Glass M, Burdick MK, Strieter RM. (1996) Inhibition of IL-8 reduces tumorigenesis of human non-small cell lung cancer in SCID mice. J. Clin. Invest. 97: 2792-2802.

9. David JR. (1996) Delayed hypersensitivity in vitro: its mediation by cell free substances formed by lymphoid cell-antigen interaction. Proc. Natl. Acad. Sci. U.S.A. 56: 72-77.

10. Bloom BR, Bennet B. (1966) Mechanism of a reaction in vitro associated with delayed-type hypersensitivity. Science 153: 80-82.

11. Bacher MB, Metz CN, Calandra T, et al. (1996) An essential role for macrophage migration inhibitory factor in T-cell activation. Proc. Natl. Acad. Sci. U.S.A. 93: 7849-7854.

12. Calandra T, Bernhagen J, Mitchell RA, Bucala R. (1994) The macrophage is an important and previously unrecognized source of macrophage migration inhibitory factor. J. Exp. Med. 179: 8951902.

13. Calandra T, Bernhagen J, Metz CN, et al. (1995) MIF as a glucocorticoid-induced counter-regulator of cytokine production. Nature 377: 68-71.

14. Bernhagen J, Calandra T, Mitchell RA, et al. (1993) MIF is a pituitary-derived cytokine that potentiates lethal endotoxaemia. Nature 365: 756-759.

15. Bernhagen J, Bacher M, Calandra T, et al. (1996) An essential role for MIF in the tuberculin delayed-type hypersensitivity reaction. J. Exp. Med. 183: 277-282.

16. Calandra T, Spiegel LA, Metz CN, Bucala R (1998) Macrophage migration inhibitory factor (MIF) is a critical mediator of the activation of immune cells by exotoxins of gram-positive bacteria. Proc. Natl. Acad. Sci. U.S.A. 95: 11383-11388.

17. Kemp JD, Cardillo T, Stewart BC, et al. (1995) Inhibition of lymphoma growth in vivo by combined treatment with hydroxyethyl starch deferoxamine conjugate IgG monoclonal antibodies 
against the transferrin receptor. Cancer Res. 55: 3817-3824.

18. Taetle R, Rosen F, Abramson I, Venditti J, Howell S. (1987) Use of nude mouse xenografts as preclinical drug screens: in vivo activity of established chemotherapeutic agents against melanoma and ovarian carcinoma xenografts. Cancer Treatment Rep. 71: 297-304.

19. Zar JH. (1984) Biostatistical Analysis. Prentice-Hall, Englewood Cliffs, NJ.

20. Waeber G, Calandra T, Roduit R, et al. (1997) Insulin secretion is regulated by the glucose-dependent production of islet $\beta$-cell macrophage migration inhibitory factor (MIF). Proc. Natl. Acad. Sci. U.S.A. 94: 4782-4787.

21. Bernhagen J, Mitchell RA, Calandra T, Voelter W, Cerami A, Bucala R. (1994) Purification, bioactivity, and secondary structure analysis of mouse and human MIF. Biochemistry 33: 14144-14155.

22. Passanti A, Taylor RM, Pili R, et al. (1992) A simple, quantitative method for assessing angiogenesis and antiangiogenic agents using reconstituted basement membrane, heparin, and fibroblast growth factor Lab. Invest. 67: 519-528.

23. Bergman Y, Haimovich J. (1977) Characterization of a carcinogen-induced murine B lymphocyte cell of $\mathrm{C} 3 \mathrm{H} / \mathrm{eB}$ origin. Eur. J. Immunol. 7: 413-417.

24. Campbell MJ, Esserman L, Levy R. (1988) Immunotherapy of established murine $B$ cell lymphoma. Combination of idiotype immunization and cyclophosphamide. J. Immunol. 141: 32273233.

25. Basham TY, Palladin MA, Badger CC, Bernstein ID, Levy R, Merigan TC. (1988) Comparison of combinations of interferons with tumor specific and nonspecific monoclonal antibodies as therapy for murine $\mathrm{B}$ cell and $\mathrm{T}$ cell lymphomas. Cancer Res. 48: 4196-4200.

26. Kaminski MS, Kitamura K, Maloney DG, Levy R. (1987) Idiotype vaccination against murine $B$ cell lymphoma. Inhibition of tumor immunity by free idiotype protein. J. Immunol. 138: 1289-1296.

27. Folkman J, Cotran R. (1976) Relation of vascular proliferation to tumor growth. Int. Rev. Exp. Pathol. 16: 207-248.

28. Gimbrone MA, Leapman SB, Cotran R, Folkman
J. (1972) Tumor dormancy in vivo by prevention of neovascularization. J. Exp. Med. 136: 261-276.

29. Folkman JK, Watson D, Ingber D, Hanahan J. (1989) Induction of angiogenesis during the transition from hyperplasia to neoplasia. Nature 339: 58-61.

30. Vecchi AC, Garlanda C, Lampugnani MG, et al. (1994) Monoclonal antibodies specific for endothelial cells of mouse blood vessels. Their application in the identification of adult and embryonic endothelium. Eur. J. Cell Biol. 63: 247-254.

31. Xie Y, Muller WA. (1993) Molecular cloning and adhesive properties of murine platelet/endothelial adhesion molecule-1. Proc. Natl. Acad. Sci. U.S.A. 90: 5569-5573.

32. DeLisser HM, Newman PJ, Albeda SM. (1993) Platelet endothelial cell adhesion molecule (CD31). Curr. Top. Microbiol. Immunol. 184: 37-45.

33. Buck CA, Baldwin HS, DeLisser H, et al. (1993) Cell adhesion receptors and early mammalian heart development-an overview. C R Acad. Sci. III 316: 849-859.

34. Bacher MB, Meinhardt A, Lan HY, et al. (1997) Migration inhibitory factor expression in experimentally induced endotoxemia. Am. J. Pathol. 150: 235-246.

35. Whalen GF, Zetter BR. (1992) Angiogenesis. In: Wound Healing, W. B. Saunders, Philadelphia, pp. 77-95.

36. Folkman J, D'Amore PA. (1996) Blood vessel formation: what is its molecular basis? Cell 87: 11531155.

37. Fiorentino MV. (1991) Lymphomas in the elderly. Leukemia 5: 79-85.

38. Goss PE. (1992) New perspectives in the treatment of non-Hodgkin's lymphoma. Semin. Oncol. 19: 23-29.

39. Zackheim HS. (1994) Treatment of cutaneous Tcell lymphoma. Semin. Dermatol. 13: 207-215.

40. Sun HW, Bernhagen J, Bucala R, Lolis E. (1996) Crystal structure at 2.6-A resolution of human macrophage migration inhibitory factor. Proc. Natl. Acad. Sci. U.S.A. 93: 5191-5196.

41. Rosengren E, Bucala R, Aman P, et al. (1996) The immunoregulatory mediator MIF catalyzes a tautomerization reaction. Mol. Med. 2: 143-149. 